\title{
Interleukin-4 Cytokine as an Indicator of the Severity of Tuberculous Lymphadenitis
}

\author{
Humairah Medina Liza Lubis ${ }^{1 *}$, Mohd Nadjib Dahlan Lubis², Delyuzar Delyuzar ${ }^{3}$ \\ ${ }^{1}$ Department of Anatomical Pathology, Faculty of Medicine, Universitas Muhammadiyah Sumatera Utara, Medan, Indonesia; \\ ${ }^{2}$ Department of Anatomical Pathology, Faculty of Medicine, Universitas Islam Sumatera Utara, Medan, Indonesia; ${ }^{3}$ Department \\ of Anatomical Pathology, Faculty of Medicine, Universitas Sumatera Utara, Medan, Indonesia
}

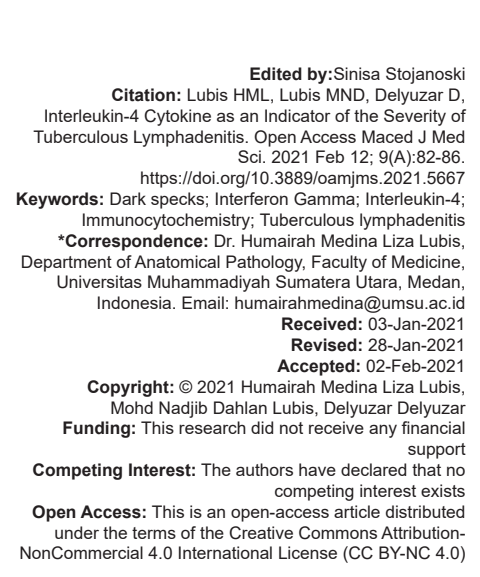

\begin{abstract}
BACKGROUND: Interleukin-4 (IL-4) is a cytokine of Th2 response and plays a role as a reducer or silencer of Th1 work. It is more related to allergic processes, with consequent loss of control of the disease (i.e., tuberculosis) Interferon gamma (IFN- $\gamma$ ) is a Type II interferon that inhibits Th2 immune response and inducts Th1 immune response to inhibit tuberculous and viral replication, and any immunostimulatory and immunomodulatory effects. Dark specks (DS) are in the background of eosinophilic granular material seen in aspirations of tuberculous lymphadenitis stained with May-Grunwald Giemsa (MGG). A lesion with DS festers and the disease worsens.

AIM: This study determines whether the expression of IL-4 is associated with disease severity and compares incidences of expression of IL-4 and IFN- $\gamma$ in DS lesions.

MATERIALS AND METHODS: This study includes 100 diagnostic cases of tuberculous lymphadenitis, which were not successfully treated with common antibiotics, but responded to anti-tuberculous drugs (ex juvantibus diagnosis). Out of the 100 cases, 59 cases were with DS and 41 cases were without DS. Out of the 59 cases with DS, 49 cases were IL-4 positive $(+)$ and 10 cases IL-4 negative $(-)$. Of the 41 cases without DS, 10 cases were IL-4 (+) and 31 cases were IL-4 (-). Out of the 59 cases of DS, there were 31 cases with expressions of IL-4 (+) and IFN- $\gamma(-)$ zero case with IL-4 (-) and IFN- $\gamma(+)$; 18 cases with IL-4 (+) and IFN- $\gamma(+)$; and 10 cases with IL-4 (-) and IFN- $\gamma(-)$. Antigen expressions were determined using rabbit polyclonal to IL-4 (IL-4, ab9622) and rabbit polyclonal to IFN- $\gamma$ (IFN- $\gamma$, ab9657), Abcam. Statistical evaluations were performed using the Chi-square test and Fisher's exact test. Any $p<0.05$ was statistically significant.
\end{abstract}

RESULTS: Expression of IL-4 significantly associated with disease severity, compared to IFN- $\gamma$ expression $(p<0.05)$ In lesions with DS, IL-4 is more frequently expressed compared with IFN- $\gamma$.

CONCLUSION: IL-4 can be a beneficial indicator of the severity of tuberculous lymphadenitis.

\section{Introduction}

We categorize tuberculosis (TB) as a global health issue that significantly impacts Indonesia. According to the WHO, TB is the leading cause of death from a single infectious agent [1]. Lymph nodes are the most common location of extrapulmonary TB. We can find the incidence of TB lymphadenitis in about $15-20 \%$ of all TB cases [2].

Classically, cytological diagnosis of TB is established through the discovery of epithelioid histiocytes cells in the background of lymphocytes, multinucleated giant cells of the foreign body type, or Langhans type giant cells. They may or may not show necrosis [3]. In some tuberculous cases, however, these classic diagnoses are not observed; instead, dark specks (DS) are present.

DS, as suggested by their name, are rather blackish flecks in the background of eosinophilic granular material, as seen through aspiration on the biopsy specimen of tuberculous lymphadenitis when stained with May-Grunwald Giemsa (MGG). A lesion with DS often festers, worsening the disease.

Interleukin-4 (IL-4) is a cytokine of Th2 response and plays a role as a reducer or silencer of Th1 and is more related to allergic processes, consequently leading to the loss of control of the disease (i.e., TB). Interferon gamma (IFN- $\gamma$ ) is a Type II interferon that inhibits both the Th2 immune response and further induction of Th1 immune response. It inhibits tuberculous and viral replication from its immunostimulatory and immunomodulatory effects.

This study determines whether the IL-4 expressions are associated with disease severity and compares the incidence of IL-4 expressions and IFN- $\gamma$ in DS lesions. 


\section{Materials and Methods}

\section{Sample collection}

This cross-sectional study used 100 smears of aspirate, obtained using an aspiration biopsy of lymph nodes, collected from the Anatomy Pathology Diagnostic Center of the Faculty of Medicine, University of North Sumatra, Medan, Indonesia. For each case, we prepared at least three separate smears of MGG stain and IL-4 and IFN- $\gamma$ immunocytochemistry tests.

Overall, we diagnosed cases with TB. We confirmed each diagnosis ex juvantibus, which refers to making an inference about disease causation from an observed response of the potential disease to treatment. These TB cases were treated initially with common antibiotics, which were unsuccessful; however, they were treated successfully with anti-TB drugs. In this case, each diagnosis was made based on a successful treatment response to anti-TB drugs.

We based identification of DS on the presence of cytological features, using an eosinophilic fine granular amorphous mass in the background seen on aspirate stained with MGG.

\section{examination \\ Fine-needle aspiration cytology}

We obtained the smears using fine-needle aspiration, performed by a pathologist using a $20-23-G$ needle $(30-50 \mathrm{~mm}), 10 \mathrm{ml}$ of a disposable syringe, and pistolet (Comeco Swedia). We stained the specimens with the MGG staining procedure.

\section{Immunocytochemistry examination}

The cases were stained immunocytochemically with rabbit polyclonal to anti-IL-4 (IL-4, ab9622) and rabbit polyclonal to anti-IFN- $\gamma$ (IFN- $\gamma$, ab9657), Abcam. After washing the slide for a short time in phosphate-buffered saline, we incubated the slides with hydrogen peroxide for $30 \mathrm{~min}$ to inhibit endogenous peroxidase activity. After taking the microwave antigen and blocking the items with $5 \%$ serum horse (NHS) for 15 min, we treated the slides with a primary antibody: Rabbit polyclonal to anti-IL-4 (IL-4, ab9622) and rabbit polyclonal to antiIFN- $\gamma$ (IFN- $\gamma$, ab9657) (Abcam, London, England) at $1 / 100$ dilution overnight. The slides were then treated with Dako Real EnVision. We visualized the antigen with diaminobenzidine and anti-staining with hematoxylin.

\section{Evaluation of immunostaining}

In each slide, stained materials were categorized as either positive or negative. The assessment did not measure the intensity of cytokines expression.

\section{Research protocol}

We divided the cases into two groups: 59 with DS and 41 without DS. Out of the 59 cases with DS, 49 cases were IL-4 positive (+) and 10 cases IL-4 negative $(-)$. Out of the 41 cases without DS, 10 cases were IL-4 (+) and 31 cases were IL-4. Of the 59 cases with DS, there were 31 cases with expressions of IL-4 (+) and IFN- $\gamma(-)$; zero case with IL-4 (-) and IFN- $\gamma(+)$; 18 cases with IL-4 (+) and IFN- $\gamma(+)$; and 10 cases with IL-4 $(-)$ and IFN- $\gamma(-)$.

\section{Statistical analysis}

We conducted Chi-square and Fisher's tests to determine the relationship between the two variables. $p<0.05$ was considered to be significant in this study.

\section{Results}

The age of patients ranged from 18 to 61 , with majority aged $21-30$ years. The ratio of female to male is 1.8: 38 cases $(64.4 \%)$ identified as female and 21 cases $(35.6 \%)$ identified as male.

The lymph node was primarily involved in 49 cervical cases $(83.1 \%) ; 7$ supraclavicular cases (11.9\%); 2 submandibular cases (3.4\%); and 1 inguinal case $(1.7 \%)$.

\section{Cytology}

We observed a characteristic lesion with DS, as shown in Figure 1. DS were rather dark-colored stuff in the background of eosinophilic granular material seen on aspiration biopsy specimen of tuberculous lymphadenitis stained with MGG.

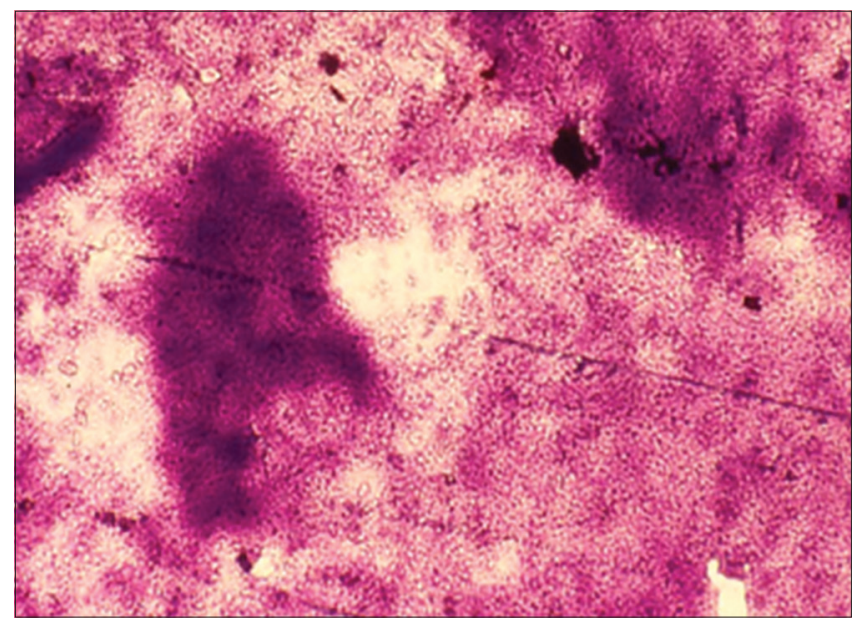

Figure 1: Aspirate of the lesion with dark specks (DS), with an eosinophilic fine granular amorphous mass in the background (DS) (May-Grunwald Giemsa, 400×) 
We observed lesions without DS, as shown in Figure 2. Lymphocytes, macrophages, and lymphoblasts.

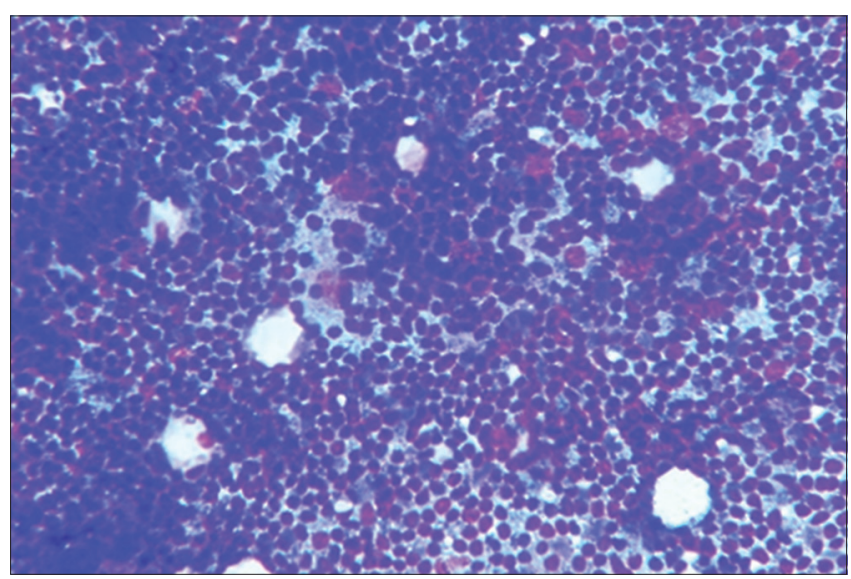

Figure 2: Aspirate of the lesion without dark specks (May-Grunwald Giemsa, 400×)

\section{Comparison between IFN- $y$ and IL-4 in DS}

Positive IL-4 and negative IFN- $\gamma$ expressions were observable on both lesions with DS, as shown in Figures 3 and 4, respectively.

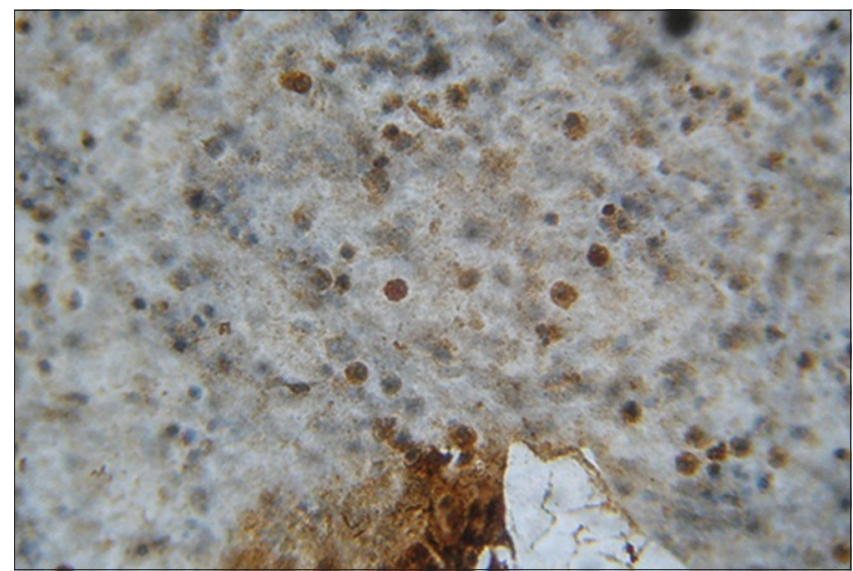

Figure 3: Positive interleukin-4 expression in dark speck (immunocytochemistry, 400x)

There was a significant difference in the expression of IL-4 and IFN- $\gamma$ cytokines in the lesions with DS $(p<0.05)$ (Tables 1 and 2$)$.

Table 1: IL-4 expression on lesions with DS and without DS

\begin{tabular}{lllll}
\hline Lesion IL-4 & DS (\%) & Without DS $(\%)$ & Total $(\%)$ & p-value \\
\hline Positive & $49(49)$ & $10(10)$ & $59(59)$ & 0.000 \\
Negative & $10(10 \%)$ & $31(31 \%)$ & $41(41 \%)$ & \\
Total & $59(59)$ & $41(41)$ & $100(100)$ & \\
\hline
\end{tabular}

${ }^{*}$ Chi-square test: $p<0,05$, IL-4: Interleukin-4, DS: Dark specks.

\section{Discussion}

Blackish spots were visible in the background of eosinophilic fine granulated amorphous material, which was smear stained with MGG. We called these DS [4], [5]. These are apparently the same as what
Pandit et al. [6] described as eosinophilic structure, degenerated granulomas, acellular, and necrotic material. Prasoon and Agrawal [7] and Chikkannaiah et al. [8] reported on aspiration biopsies yielding necrotic material and showed acid-fast bacilli in $58.33 \%$ and $39 \%$ of cases of tuberculous lymph nodes, respectively. The study using PCR on 95 cases of positive tuberculous cases (with DS) and 99 negative cases (without DS) discovered a sensitivity value of $98.95 \%$ and a specificity value of $96.97 \%$ [9].

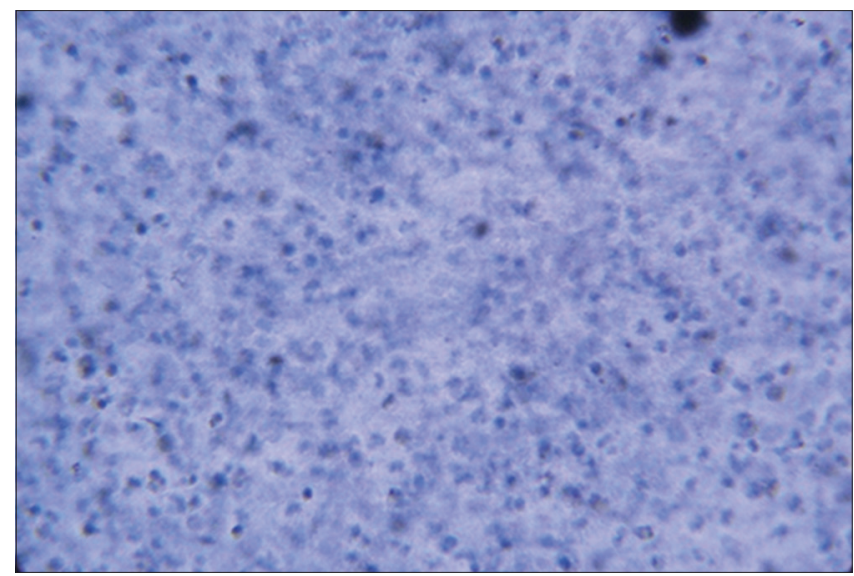

Figure 4: Negative interferon gamma expression in dark speck (immunocytochemistry, 400x)

The previous studies have suggested that DS are related to TB. These are consistent with several additional studies that prove that DS are a signifier of TB. Our findings build on the Lubis TB antibody study (ab905); the Delyuzar study on PCR; the Balaji study treating 135 children with regular antibiotics without success; and the Muyanja study on histopathological confirmation [4], [5], [9], [10], [11].

Table 2: IL-4 and IFN-gamma expressions on lesions with dark specks

\begin{tabular}{lllll}
\hline IL-4 IFN- $\mathrm{Y}$ & Positive (\%) & Negative $(\%)$ & Total $(\%)$ & p-value $^{*}$ \\
\hline Positive & $18(30)$ & $0(0)$ & $18(30)$ & $0.024^{*}$ \\
Negative & $31(53)$ & $10(17)$ & $41(70)$ & \\
Total & $49(83)$ & $10(17)$ & $59(100)$ & \\
\hline
\end{tabular}

We know that delayed-type hypersensitivity reactions are involved in the TB process. Several studies have shown the importance of cytokines as indicators of TB activity. Cytokines have pleiotropic and regulatory effects and take part in host defense and the process of inflammation and tissue repair [12]. In addition, several cytokines are known to be involved in anti-TB responses, including IFN- $\gamma$, TNF- $\alpha$, IL-6, IL-10, and VEGF. Nevertheless, the role of IL-4 is still disputed.

In this study, we reveal the inverse relationship between IFN- $\gamma$ and IL-4 expression in DS. This finding is consistent with the immunological theory asserting the necessary balance of Th1 and Th2 in chronic infectious diseases. IFN- $\gamma$ will strengthen the phagocyte potential of Mycobacterium tuberculosis-infected macrophages by stimulating phagolysosome formation and stimulating the formation of free radicals that can destroy $M$. tuberculosis components by increasing reactive nitrogen intermediate [13]. 
IL-4 mediates the humoral immune response and provides anti-inflammatory effects by inhibiting the production of pro-inflammatory cytokines and changing the profile of macrophage expression. Prior research on human TB, such as that conducted by Lin et al. and Zhang et al., has described a decrease in Th1 response [14], [15].

Increased IL-4 production through the Th2 immune response will suppress the work of the Th1 response, which ultimately leads to failure in bacterial elimination and the development of the bacilli intracellularly [16], [17]. In addition, IL-4 will reduce IFN- $\gamma$ production and induce activation of the Th2 response, resulting in adverse effects in TB patients.

Several studies have reported that overexpression of Th2 cytokines increases the severity of TB, including the observation that virulent M. tuberculosis strains induce Th2 cytokine expression, whereas less virulent strains induce Th1 cytokines, including IFN- $\gamma$ and TNF- $\alpha$ [18], [19]. IL-4 can be considered as a potential indicator for active TB. This is seen especially in TB patients residing in tropical regions of the world [20], [21]. Overexpression of IL-4 induces progressive disease [22] and reactivation of latent infection [23] in mice infected with M. tuberculosis. Increased IL-4 production has also been detected in TB patients, especially those with cavity disease. Furthermore, IL-4 expression increases, especially in patients with cavernous TB. Findings have shown that Th2 type responses increased IL-4 production in patients with TB, which can trigger defenses and cause tissue necrosis [24].

Our study reveals that IL-4 is widely expressed in DS. We suggest that IL-4 expressed in DS can aid in diagnosis and help determine the severity of TB. Our findings align with an additional study which demonstrates that the expression of IL-4 tends to cause necrosis as the disease progresses [25].

With the expression of IL-4 (red), the use of anti-cytokine drugs may be more effective for treatment, especially for TB patients whose cases are resistant to anti-tuberculous medications.

\section{Conclusion}

IL-4 cytokine is a potential indicator of advanced disease progression in TB lymphadenitis and is correlated with the presence of DS.

\section{Declaration of interest}

The authors would like to state that this study has no conflicts of interest and has followed all ethical consideration agreed by the Health Research Ethical Committee of the Faculty of Medicine, University of North Sumatera/H. Adam Malik General Hospital with No. 580/TGL/KEPK FK USU-RSUP HAM/2019. Verbal consent was given by the participants of the study.

\section{References}

1. World Health Organization. Global Tuberculosis Report. France: World Health Organization; 2018.

2. Mohapatra PR, Janmeja AK. Tuberculous lymphadenitis. J Assoc Physicians India. 2009;57:585-90.

PMid:20209720

3. Koss LG. Koss' Distic Cytgy and Its Histopathologic Bases. United States: Lippincott Williams \& Wilkins; 2006. Available from: https://www.books.google.co.id/book/about/koss_diagnostic_ cytology_and_its_histopa.html?id=yuvhjjshhpec\&redir esc=y. https://doi.org/10.1016/s0031-3025(16)39681-7. [Last accessed on 02 Jun 2019].

4. Lubis HMD, Lubis HML, Lisdine Lisdine, Hastuti NW. Dark specks and eosinophilic granular necrotic material as differentiating factors between tuberculous and nontuberculous Abscess. Majalah Patologi Indonesia. Majalah Patologi Indonesia. 2008; 2:49-52.

5. Lubis HML. Badan-Badan Kecil Berbentuk Oval Gelap didalam Kelompokan Makrofag dan Bercak-bercak Gelap: Dua Struktur Terabaikan dalam Diagnosis Limfadenitis Tuberkulosis, Universitas Sumatera Utara; 2011. Available from: http://www. repository.usu.ac.id/handle/123456789/26817. [Last accessed on 02 Jun 2019].

6. Pandit AA, Khilnani PH, Prayag AS. Tuberculous lymphadenitis: Extended cytomorphologic features. Diagn Cytopathol. 1995;12(1):23-7. https://doi.org/10.1002/dc.2840120106 PMid:7789241

7. Prasoon D, Agrawal P. Correlation of eosinophilic structures with detection of acid-fast bacilli in fine needle aspiration smears from tuberculous lymph nodes: Is eosinophilic structure the missing link in spectrum of tuberculous lesion? J Cytol. 2014;31(3):149-53. https://doi.org/10.4103/0970-9371.14564 PMid:25538384

8. Chikkannaiah P, Boovalli MM, Venkataramappa SM. Eosinophilic structure: Should it be included in routine cytology reporting of tuberculosis lymphadenitis? J Clin Diagn Res. 2015;9(12):EC057. https://doi.org/10.7860/jcdr/2015/15631.6862

PMid:26816895

9. Delyuzar Delyuzar. Korelasi Antara Massa Eosinofilik Dengan Partikel Coklat Gelap Dengan Mycobacterium Tuberculosis Pada Sitologi Biopsi Aspirasi. Indonesia: Universitas Sumatera Utara; 2019.

10. Balaji J, Sundaram SS, Rathinam SN, Rajeswari PA, Kumari ML. Fine needle aspiration cytology in childhood TB lymphadenitis. Indian J Pediatr. 2009;76(12):1241-6. https://doi.org/10.1007/ s12098-009-0271-2

PMid:19936644

11. Muyanja D, Kalyesubula R, Namukwaya E, Othieno E, MayanjaKizza H. Diagnostic accuracy of fine needle aspiration cytology in providing a diagnosis of cervical lymphadenopathy among HIV-infected patients. Afr Health Sci. 2015;15(1):107-16. https:// doi.org/10.4314/ahs.v15i1.15

PMid:25834538 
12. Gupta M, MacNeil A, Reed ZD, Rollin PE, Spiropoulou CF. Serology and cytokine profiles in patients infected with the newly discovered bundibugyo ebolavirus. Virology. 2012;423(2):11924. https://doi.org/10.1016/j.virol.2011.11.027 PMid:22197674

13. Abbas AK, Lichtman AH, Pillai S. Basic Immunology: Functions and Disorders of the Immune System. Philadelphia, PA Elsevier, Saunders; 2019. Available from: https://www.elsevier. com/books/basic-immun78-0-323-54943-1. [Last accessed on 02 Jun 2019].

14. Lin $Y$, Zhang M, Hofman FM, Gong J, Barnes PF. Absence of prominent Th2 cytokine response in human tuberculosis. Infect Immun. 1996;64(4):1351-6. https://doi.org/10.1128/ iai.64.4.1351-1356.1996 PMid:8606100

15. Zhang M, Lin Y, lyer DV, Gong J, Abrams JS, Barnes PF. T-cell cytokine responses in human infection with Mycobacterium tuberculosis. Infect Immun. 1995;63(8):3231-4. https://doi. org/10.1128/iai.63.8.3231-3234.1995 PMid:7622255

16. Ma MJ, Xie LP, Wu SC, Tang F, Li H, Zhang ZS, et al. Tolllike receptors, tumor necrosis factor- $\alpha$, and interleukin-10 gene polymorphisms in risk of pulmonary tuberculosis and disease severity. Hum Immunol. 2010;71(10):1005-10. https://doi. org/10.1016/j.humimm.2010.07.009

PMid:20650298

17. Wu S, Wang Y, Zhang M, Wang M, He JQ. Genetic variants in IFNG and IFNGR1 and tuberculosis susceptibility. Cytokine. 2019;123:154775. https://doi.org/10.1016/j.cyto.2019.154775 PMid:31310896

18. Surewicz K, Aung H, Kanost RA, Jones L, Hejal R, Toossi Z. The differential interaction of p38 MAP kinase and tumor necrosis factor-alpha in human alveolar macrophages and monocytes induced by Mycobacterium tuberculois. Cell Immunol. 2004;228(1):34-41. https://doi.org/10.1016/j. cellimm.2004.03.007
PMid:15203318

19. Freeman S, Post FA, Bekker L-G, Harbacheuski R, Steyn LM, Ryffel B, et al. Mycobacterium tuberculosis H37Ra and H37Rv differential growth and cytokine/chemokine induction in murine macrophages in vitro. J Interferon Cytokine Res. 2006; 26(1):2733. http://doi.org/10.1089/jir/2006.26.27. PMid: 16426145.

20. Mazzarella G, Bianco A, Perna F, D'Auria D, Grella E, Moscariello $\mathrm{E}$, et al. $\mathrm{T}$ lymphocyte phenotypic profile in lung segments affected by cavitary and non-cavitary tuberculosis. Clin Exp Immunol. 2003;132(2):283-8. https://doi. org/10.1046/j.1365-2249.2003.02121.x

PMid: 12699418

21. Dheda K, Chang JS, Breen RA, Haddock JA, Lipman MC $\mathrm{Kim}$ LU, et al. Expression of a novel cytokine, IL-4delta2, in HIV and HIV-tuberculosis co-infection. AIDS. 2005;19(15):1601-6. https://doi.org/10.1097/01.aids.0000183520.52760.ef PMid:16184029

22. Hernández-Pando R, Orozcoe $H$, Sampieri A, Pavón L, Velasquillo C, Larriva-Sahd $\mathrm{J}$, et al. Correlation between the kinetics of Th1, Th2 cells and pathology in a murine model of experimental pulmonary tuberculosis. Immunology. 1996;89(1):26-33.

PMid:8911136

23. Howard AD, Zwilling BS. Reactivation of tuberculosis is associated with a shift from Type 1 to Type 2 cytokines. Clin Exp Immunol. 1999;115(3):428-34. https://doi. org/10.1046/j.1365-2249.1999.00791.x

PMid: 10193414

24. van Crevel R, Ottenhoff TH, van der Meer JW. Innate immunity to Mycobacterium tuberculosis. Clin Microbiol Rev. 2002;15(2):294309. https://doi.org/10.1128/cmr.15.2.294-309.2002 PMid:11932234

25. Soyer OU, Akdis M, Akdis CA. Mechanisms of subcutaneous allergen immunotherapy. Immunol Allergy Clin North Am. 2011;31(2):175-90. https://doi.org/10.1016/j.iac.2011.02.006 PMid:21530813 